\title{
BLOOD UREA NITROGEN DURING THE FIRST 2 WEEKS OF LIFE IN VLBW INFANTS RECEIVING HIGH PROTEIN INTAKES
}

T. Senterre, J. Rigo

University of Liège, Liège, Belgium

Objective: High protein intakes have been associated with elevated blood urea nitrogen (BUN). This study evaluated BUN values in VLBW infants receiving high protein intakes postnataly according to recent recommendations.

Methods: BUN were evaluated in 102 infant with a birth weight $<1250 \mathrm{~g}$ during the first 2 weeks of life. Analyses were evaluated during 3 periods of 5 days. Protein intake was $2.4 \pm 0.3,3.8 \pm 0.6$ and $4.0 \pm 0.6 \mathrm{~g} / \mathrm{kg} * \mathrm{~d}$ on the first day, after 1 week and after 2 weeks respectively.

Results: 102 infants were included $(\mathrm{BW}=1005 \pm 157 \mathrm{~g}, \mathrm{GA}=25.5 \pm 1.9 \mathrm{wks})$. Simple correlation analyses demonstrated that BUN decreased with protein intakes $(\mathrm{r}=-0.16, \mathrm{p}<0.01)$, postnatal age $(\mathrm{r}=-0.21, \mathrm{p}<0.01)$ and enteral feeding progression $(\mathrm{r}=-0.40, \mathrm{p}<0.01)$; and BUN increased with blood creatinine values $(\mathrm{r}=0.71, \mathrm{p}<$ $0.01)$ and postnatal weight loss $(\mathrm{r}=0.33, \mathrm{p}<0.01)$. Similar correlations were observed during the 3 periods.

Multivariate analysis demonstrated that the major independent factor influencing BUN was blood creatinine value, explaining $\sim 50 \%$ of the value. Protein intakes explained $\sim 1 \%$ of urea value during the first 2 weeks of life.

Conclusions: BUN may not be interpreted in term of protein tolerance during the first 2 weeks of life in VLBW infants. BUN was mainly determined by renal function during early postnatal period. 